\title{
DISPARITIES IN THE MULTIMODAL REPRESENTATION OF INFORMATION IN ENGLISH AND BULGARIAN LANGUAGE FOOD ADVERTISEMENTS
}

\section{Rumyana Todorova ${ }^{1}$}

\begin{abstract}
The paper deals with various ways of presenting information in the verbal and the nonverbal components of British and Bulgarian food advertisements in a number of inconsistent and discrepant manifestations which provoke wrong guesses, hypotheses and presuppositions on part of text receivers and make them change the latters' own axis of orientation and direction of thought as the narrative develops. These manipulative techniques on part of advertising agents lead to interestingness and curiosity on behalf of potential consumers towards the plot and the story, which will inevitably bring about desired expectations.
\end{abstract}

Key words: disparities, inconsistencies, discrepancies, multimodality

\section{Introduction}

As the world is getting more and more saturated and overflooded with all sorts of information presented in sensational and at times even fake ways, text producers are doing their best not only to grab people's attention but to keep it at least for a while by using tantalising and provocative techniques. As for advertising agents, they construct texts which have always been provocative enough for text receivers to consider them either positively or negatively. The idea is for the messages to play a leading role in shaping consumers' opinions and controlling their consciousness by directing their orientation from the 'what' (related to product or service) to the 'why' (related to the reason of availing ourselves of the offers) because what matters first and foremost is rather how the product/ service makes us feel than how it satisfies our needs and demands.

\section{Previous research in the field}

The meaning of disparity as used in the paper has to do with 'incongruity', 'discrepancy' and 'inadequacy' rather than with the issue of 'inequality'. Disparity in the sense of 'inequality' has often been exploited in the field of advertising as regards gender differences and biases, which is not the aim of the

1 Professor PhD at Shumen University, Department of English Studies, Shumen, Bulgaria, e-mail: r.todorova@shu.bg 
present study. An example, closely related to the idea of disparity in the latter sense, can be the often discussed question of obesity epidemic, not directly mentioned in advertising discourse, but the end result as a consequence of various texts of this type is pretty obvious as it deals with food advertising which "serves as a prompt for automatic eating" (Cassady, Liaw \& Miller, 2015). Disparity in this respect is sometimes oriented towards inequality based on racial and high- and low-income factors and refers mostly to outdoor advertising concerning unhealthy versus healthy food offers (Lesser, Zimmerman \& Cohen, 2013). There is quite a lot of research in this field, e.g. on Coca-Cola and Macdonald's promotions, to name but a few. Thus, for example, the author has conducted small-scale research on the expectation effects in Bulgarian advertising (Todorova, 2016) and on incongruity in advertising as a prerequisite for conflict, change or adaptation of schemas (Todorova, 2013). In 'America (Real or Imagined) in Ads through the Eyes of the Beholder', the author touches upon some differences between the advertised goods and the ways they are described, as is the case with Coca-Cola ads which bring about happiness and fun in people at the expense of healthy food and nutritious low-calorie products (Todorova, 2002). There is another study by McKenzie, Bugden and Webster (2018) related not to food promotion but to gender inequality and to women's health in particular "Advertising (in)equality: the impacts of sexist advertising on women's health and wellbeing". The whole of December 2018 A Women's Health Victoria Issues Paper is dedicated to women's inequality. The interdependence between food and gender, however, is presented by Lerner (2016). This is just a small portion of the research conducted on disparity in advertising discourse.

In the present paper dealing with some food advertisements, disparity is related to some kind of disproportion or mismatch in the information in the verbal and the nonverbal component which is applied for the sake of achieving sensation and interestingness towards the object of attention.

\section{Methods}

The methods used for the analysis of the selected advertisements out of a larger corpus are Multimodal Critical Discourse Analysis (MCDA) and cognitive linguistics in the verbal and the nonverbal components of the ad narratives. While Critical Discourse Analysis (CDA) deals mostly with explorations of verbal components and does not extend beyond that parameter, it still analyses and takes into account the social practices the text is constructed in (Fairclough, 1995; Huckin, 1997; Todorova, 2015). However, MCDA elaborates on issues presented in both components of any text, the advertising text being one of them, as the nonverbal component carries the information load to the greatest extent in a number of cases (Machin \& Mayr, 2012; Royce \& Bowcher, 2006). 
As stated by Ledin and Machin $(2018$, p. 6), MCDA concerns "the contents, the canons of use and the social practices involved", which comes to prove the fact that these two methods of analysis - CDA and MCDA - have a lot in common and in some cases they are hard to differentiate. As for the cognitive linguistics analysis, it is applied in connection with the metaphoric usages in the described samples. The combination of MCDA and cognitive linguistics is inevitable as the texts under investigation abound in various manifestations of rendering ad messages. In this respect, a useful and invaluable source is Charles Forceville's study on pictorial and multimodal metaphor (Forceville, 2016), which serves as a point of orientation in the presented analysis.

\section{Data Analysis}

The current paper is part of a bigger study in which disparity is considered to be an issue of multimodal advertisements. The potential mappings of ideas related to the promoted goods are constructed on the basis of presenting various phenomena in different ways. In most cases, the resolution of the information in question relies heavily on resemblance and/ or similarity between the information in the verbal and in the nonverbal component which can be facilitated with the help of potential consumers' background knowledge and their "cognitive flexibility" (Forceville, 2016). But in a great number of advertising texts, consumers' range of expectations differs to a certain extent and it can either steer their interpretations towards the direction desired by advertising agents or constrain them for some reason, which can be caused by a complete lack of understanding of the message or misunderstanding. In this respect, text recipients should be willing to adapt or at times even modify their understanding of the world so that they could contextualise two seemingly different schemas on one and the same plane. Thus, according to Šorm and Steen "consumers use deviation from expectation" (Šorm \& Steen, 2013, p. 3) and the "construal depends on the perceptiveness and/or the cognitive environment" of the consumers (Sperber \& Wilson, 1995, p. 38).

Following this line of thought, we can support our statement with some quite provocative advertisements about Kaufland and Billa products first, in which, as can be expected, only positive connotations are mapped from source onto target.

In both cases, the message components contain very different properties which combined together make the best of every ad, thus reminding potential buyers that they need the advertised product to the greatest extent and that it is a wellknown fact that "hunger is the best spice" according to a Chinese farmer's proverb (2017, March 13). In the proverb, hunger is used in the literal sense, but 
it can also refer to consumers' insatiable hunger for having more and more of everything. In the ads of both companies, the nonverbal components increase the desired brand perception as they can communicate complex meanings to consumers (DeRosia, 2008).

Thus, for example, the Kaufland messages chosen for the purposes of the study are oriented towards two completely different ideas, each of them creating new needs based on people's emotions, feelings, senses and instincts provoked either on a subconscious or intuitive level. In one of the batches, the mappings are onedomain as the semantic fields in both components are constructed around the notion of 'food'. The disparity, though, comes from the fact that even in the verbal component customers are presented as personae of a high social status, namely emperors, queens and princes. The tendency of advertising agents is to show target groups that brand personality is in unison with consumers' personality traits related to their self-esteem. By buying the advertised products people should feel like royalties. So, advertising often conveys values in a distorted and incongruous way; it does not create them, though. All this provides quasirealistic motivation for the presence of the source (Forceville, 2016), which stimulates potential buyers to take action. What is more, text producers exploit the fact that human decisions are not based on rational thinking only, but in most cases emotions and feelings prevail and take the upper hand. We all know that "everybody likes a compliment", a fact that Abraham Lincoln had once also mentioned (Lincoln, n.d.). That is what advertising agents are constantly doing in one way or another, either directly/ explicitly or indirectly/ implicitly, by constantly tickling their target audiences.

Thus, if potential buyers feel flattered as in the following couple of Kaufland advertisements, customers would avail themselves of the goods offered. All texts are one and the same; yet they differ in their first statement which is actually what grabs text receivers' attention:

\section{(1) Императорьт желае щедро угощение 2}

С качествени продукти от Кауфланд

Хубава седмица

(The emperor would like a generous treat

with quality products from Kaufland

(Have a) Nice week)

(2) Кралицата очаква кралски пир

(The queen is looking forward to/ expecting a king's feast)

2 Emphasis and translation: author's 


\section{(3) Принцът очаква царска трапеза}

(The prince is looking forward to/ expecting a king's feast)

(In the nonverbal component of these ads the feasts with the respective characters in them are shown).

Though these are not repetitive experiences, they have to do with learned knowledge from fairy tales dating back to our childhood and that is already enough reason for us to feel flattered, as we as humans like to hear or see things that we are aware of more than once. There is actually no semblance between the royal people and ourselves at all but by buying the products offered we will be able to feel like VIPs at least for a while by pleasing ourselves with the respective dainties. However, the disparity brings about imaginary closeness between brand identity and personal identity which leads to identity-creating relationship between two phenomena from two different categories. It is an unprecedented fact that visual resources have a greater impact than the narrative they go with. If the analysed ads had depicted only the products, very few recipients would have paid any attention to them because the element of unpredictability and surprise would be missing.

As these ads are representatives of static discourses they would definitely rely on potential mappings in one glance. The same texts appear in the form of commercials where the role of the nonverbal communication (through pictures) is greater and apart from that there is sequentiality of the narrative which is time-based, so this version of virtual reality will be much more influential and powerful as for the unfolding of the story thus helping the co-referentiality of the first-glance disparity. In principle, as Pleše and Dlačić (2015, p. 50) state "the role of nonverbal communication is repeating, conflicting, replacing and highlighting or mitigating the verbal component". In this particular case, the visual part "highlights" the information from the narrative. What matters more is that the "solving of the mystery" is postponed till later, thus increasing the in-born curiosity of every person irrespective of their age, occupation, interests, and so on and so forth. The shots seem to lack any logic thus increasing the 'curiosity'. In them, various children dressed as princes and princesses express their desires for their favourite food and meals. Even if we start making predictions about what follows, we may not think out what the commercial refers to, though the caption on the Internet under the video clip is:

(4) Кауфланд I Свежест и качество за царска трапеза

(Kaufland I Freshness and quality for a king's feast)

The disparity is disambiguated towards the end of the commercial as the plot acquires completely different dimensions and brings us back to reality and to real-life situations related to everyday shopping (https://www.youtube.com/ watch? $=$ bx431L 7mkfQ). 
The other couple of Kaufland ads (more specifically, billboards) are about family matters which is an issue having nothing to do with the products offered in Kaufland shops but quite topical in everyday communication. The two components are disparate enough but most probably it is done on purpose for the sake of triggering people's curiosity and from then on their imagination in the direction of unfolding the story, which will be different for every customer depending on their way of life and their family relations. In the first ad from this batch (5), a possible interpretation to account for the explicit disparity between the information presented in the verbal and in the nonverbal component (vegetables and fruit) can be that mothers should not worry about their daughter's unhappiness too much and what they can do is try to comfort them by providing the best food offered in Kaufland for them. The final sentence does not make any sense at all and has no obvious connection with the rest of the information. That, however, might be a good enough reason for text recipients to ponder on the whole message and interpret it in any way they like:

(5) Дьщеря ти е с разбито сърце. Отново.

Каквото и да стане.

(Your daughter is with a broken heart. Again.

Whatever happens.)

The next one (6), though, is a bit of a puzzle, difficult to solve. An idea in this respect can be that the daughter-in-law has already decided to prepare a meal which her mother-in-law will not eat because it contradicts her religious beliefs connected with fasting, but the hostess does not care much, even if her relations with her husband and his mother get worse:

(6) Свекърва ми ще идва на гости. Ама пости. Каквото и да стане.

(My mother-in-law is coming for a visit. But (she) is fasting.

Whatever happens.)

Disparity and deviation from familiar global knowledge cognitive patterns in one way or another makes it possible for the human mind to think of various reasons for this kind of presentation of the information. In the case of the following advertisements the cognitive models used for the construction of the message are completely different as regards their domains:

(7) - Как си, скыпи приятелю, (How are you, my dear friend?)

- Не ме наричай повече СКЫП (, приятелко!) (Don't call me DEAR (, my friend)

3 In the brackets - another version of the same ad. 
Защото цените се

\section{СРАВНЯВАТ ВСЯКА}

СЕДМИЦА с тези

на сравними продукти и се

АКТУАЛИЗИРАТ,

за да са винаги ниски.

(Because prices ARE COMPARED EVERY WEEK with those of comparable products and are ACTUALISED so that they can always be lower)

(брошура на Билла 10.01.-16.01.2019 г.) - в невербалния компонент - краве мляко UHT, едното на Clever)

(Billa brochure Jan. 10-16 2019) - in the nonverbal component - 2 tetra pack boxes of UHT cow milk, one of them is Clever brand)

(8) - Каква скука, скъпи мои. (Aren't you bored, my dear ones)

- Да, наистина, скъпа. (You're quite right, dear)

- Момичета, не ме наричайте повече „скъпа“. (Girls, don’t call me 'dear' any longer)

- Защо? (Why?)

- Ами, нали, всички сме с ниски цени. Чао, чао. (Well, aren't we all with low prices. Ciao, ciao.)

- Тя си отиде в Билла. (Look, she went back to Billa)

- Там е толкова приятно. (It's so pleasant there)

Опитай яйца Clever, размер М (Try Clever eggs, size M - for medium)

(9) Как си, скъпи приятелю, (How are you, my dear friend?)

- Не ме наричай повече СКЪП. (Don’t call me DEAR any longer)

- Извинявай, забравих, че днес всички сме с ниски цени. (Sorry, I forgot that today we are all with low prices)

- Да, и двамата сме евтини. (Yes, we are both cheap)

- Ей, ти пак ли към Билла? Там е толкова приятно. (Hey are you heading to Billa again? It's so pleasant there)

- До скоро. (See you soon)

Опитай краве сирене Clever../ кисело мляко Clever.. (Try Clever cow cheese../ Clever yoghurt..) 
In (7) - (9) the cognitive models on the basis of which the stories are constructed are completely different as regards their domains: of prices - cheap/ low and expensive/ dear, and of people's interrelations, which can be dear. So, text receivers are expected to match the disparities and find the intersecting points and the potential mappings as there is constant interaction between linguistic and conceptual knowledge.

In all of the above-mentioned ads there is first an explicit conflict or clash of two contexts (either in the verbal and in the nonverbal component or in one of them only), which is resolved at a later stage via lexical concepts facilitating different cognitive models. Text receivers are supposed to adapt the schemas they have constructed in their minds according to the unfolding of the story on the basis of existing cross-domain mappings and co-referentiality. The first reaction they have when coming across disparity is surprise and unexpectedness which cater to consumer desires.

There is another ad - this time about Snickers chocolate bars - which is also based on disparity as one cannot possibly expect to find spelling mistakes in an officially published text. At first sight addressees may not even notice them but they are explicitly stated and customers are even mentioned the reason why there are such 'typing mistakes' (when you're hungry):

(10) OH DEER

ITS HARD TO SPEL

WHEN YOUR HUNGRY

IF YOU KEAP MAKING TYPING MISTAKES

GRAB YOURSELF A SNICKERS FAST

SNIKKERS

VISIT OUR FACEBOOK PAGE IF YOUR NOT SHAKING TO MUTCH

https://sites.google.com/site/melanieharley99/a

(11) CHOCOLATE.

PEANUTS. VERO

CARAMEL.

CONSTRUCTIVE

CRITICISM.

SPARKY CRAY CRAY SPACE CADET

HUNGER BARS ARE BACK 
(Snickers 1; https://www.pinterest.com/pin/316237205080534619)

In (11) the disparity within the verbal component is even greater. No matter what predictions you are trying to make you cannot decide why 'CONSTRUCTIVE CRITICISM' is used and in what way it is connected with the object of attention, let alone with its characteristic features.

In (12) disparity is related to a well-known phrase coined more than 2000 years ago. It has been exploited in a number of different ways with the help of allusions. Though the mediation between the original phrase and the newly coined ones is greater, the intertextual linking is easily recognisable and there would hardly be anyone not being able to identify it:

(12) I CAME.

I SAW.

I WAS CONQUERED.

'I was conquered' can well mean 'I surrender' (in this case to the unforgettable taste of Snickers chocolate bars).

In (13) the mismatch between the written information and the advertised product is based on two-domain mappings which can serve for increasing text receivers' curiosity leading to the desired effect:

(13) IF YOU'RE

READING THIS

OUT LOUD

YOU'RE

PROBABLY

HUNGRY.

YOU'RE NOT YOU WHEN YOU'RE HUNGRY.

IF YOU'RE IN

LYCRA BUT DON'T

OWN A BIKE

YOU'RE

PROBABLY

HUNGRY.

YOU'RE NOT YOU WHEN YOU'RE HUNGRY. (Snickers 2) 
Some of the other Snickers ads rely heavily on showing the impossible by presenting various personal transformations before and after having the Snickers chocolate bar in the nonverbal component, the last one from 2018 being with the world famous singer Elton John and the British Emar Rapper featuring (Snickers 3; (14)). All of them have the same slogan 'YOU'RE NOT YOU WHEN YOU'RE HUNGRY'. The commercials about Nestle Lion bars broadcast on Bulgarian TV are similar in a way, but in them humans turn into lions thus becoming braver and stronger at times in various situations when they have one of those bars, and the slogan is „Nestle Lion Зверски вкусен” (https://www.vbox7. com/play:5f78752 5; (15)). Two opposite ideas from two completely different domains are blended into one in sensational, extraordinary and unusual ways for the sake of grabbing text receivers' attention even more with the help of these unexpected linguistic means in the verbal component. What matters is that young people, mostly teenagers use this kind of contradictory ideas when they want to emphasise the degree of likeness and positive attitude towards the object of attention. In the respective context, the primarily negative emotional colouring acquires the features of something extremely good and exceptional, the literal meaning being 'devilishly/ beastly delicious', or in proper English 'extremely delicious'. Target audiences are quite predictable; what is more, the main 'hero' in the commercials is like them, so the overt disparity, we can even call it oxymoron in this case, will definitely flatter them perfectly well and advertising agents will get to the Unique Selling Feeling they are usually aiming at. In this case, the disparity is achieved due to the 'fusion' of elements from a number of various distinct and inconsistent mental spaces as is also the case with, for example, (11) and (13).

Such advertisements will definitely be easily remembered because of the mismatch between prior knowledge and expectations, on the one hand, and the presented situation, on the other, but they may not be easily deconstructed, if at all, which means that text receivers may not be able to come to a resolution of the 'problem' cause by the disparity in the message. The reason for all this can be that there is a lack of structural and semantic correspondence between the source and the target elements in the respective context, or that, if there is, it cannot possibly be identified.

The final result, however, will be increasing brand awareness based on disparity of information as well as creating favourable brand attitudes by maintaining and preserving social norms and heavily relying on identity relationship and in some cases, on transculturalism. 


\section{Conclusion}

In general, advertising agents have some ideas expressed in the presentation of the promoted object of attention but as people are different and as they accept the world in a different way their interpretations of the reality or quasi reality against which the product is depicted will be different. However, what matters most is the fulfillment of the pleasure principle which triggers sensations, dreams and illusions while receiving information from advertisements loaded with plenty of distorted and dream-to-be realities which may eventually 'come true', if potential consumers buy the product or avail ourselves of the services offered. The disparity between the reality we live in and the created reality in advertising discourse is what does the trick in the manipulation of target audiences thus provoking human imagination and leading to the desired effect and result.

The one- and two-domain metaphoric mappings can serve as a sound and explanatory prerequisite for the success of these texts because the psychological effects can do the trick on the subconscious level and because people are curious enough to try and find the interrelations between two mutually exclusive factors presented in the multimodal mode of advertising discourse.

\section{Implications}

The implications for future research in this field can be to extend the analysis to a number of ads showing one and the same brand by different companies and use informants so that we study the way they decode the respective ads and use their imagination based on the multimodal representation of invented 'real life' stories and narratives while making their purchasing decisions. Another issue to be discussed can be to apply the Relevance Theory and see how it works in the deconstruction of advertising texts.

\section{References:}

Cassady, D. L., Liaw, K., \& Miller, L. M. (2015). Disparities in Obesity-Related Outdoor Advertising by Neighborhood Income and Race. Journal of Urban Health, 92(5), 835842. doi:10.1007/s11524-015-9980-1.

Chinese farmer's proverb. (2017, March 13). Retrieved from http://ourworldedventure.com/ 2017/03/chinese-farmers-proverb-hunger-best-spice/.

DeRosia, E. D. (2008) The Effectiveness of Nonverbal Symbolic Signs and Metaphors in Advertisements: An Experimental Inquiry, Psychology \& Marketing, 25(3), 298-316.

Fairclough, N. (2010). Critical discourse analysis. The critical study of language. $2^{\text {nd }}$ ed. London: Routledge.

Forceville C., \& Urios-Aparisi E. (Eds.) (2009). Multimodal metaphor. Berlin: Mouton de Gruyter. 
Forceville, Ch. (2016). Pictorial and multimodal metaphor. In N-M. Klug, \& H. Stöckl (Eds.). Handbuch Sprache im multimodalen Kontext. Berlin: Mouton de Gruyter. 241260.

Huckin, Th. N. (1997). Critical discourse analysis. In T. Miller (Ed.) Functional Approaches to written text: Classroom applications. Washington: English Language Programs. 7892.

Ledin, P., \& Machin, D. (2018). Doing critical discourse studies with multimodality: from metafunctions to materiality. Critical Discourse Studies, London: Routledge. Taylor \& Francis Group, 1-17.

Lerner, A. (2016). How Food Advertising Drives Gender Inequality. Retrieved May 26, 2019 from https://blogs.brown.edu/amst-0191z-s01-spring-2016/2016/05/04/how-foodadverti sing-drives-gender-inequality/.

Lesser, L. I., Zimmerman, F. J., \& Cohen, D. A. (2013). Outdoor advertising, obesity, and soda consumption: A cross-sectional study. BMC Public Health, 13(1). doi:10.1186/14712458-13-20.

Lincoln, A. (n.d.). Retrieved from https://www.brainyquote.com/quotes/abraham_\%20 lincoln_\%20151232

Machin, D., \& Mayr, A. (2012). How to Do Critical Discourse Analysis: A Multimodal Introduction. London: SAGE Publications.

McKenzie, M., Bugden, M., \& Webster, A. (2018). Advertising (in)equality: the impacts of sexist advertising on women's health and wellbeing Issues Paper. Retrieved May 26, 2019 fromhttps://www.researchgate.net/publication/329705147_Advertising_inequality_the impacts_of_sexist_advertising_on_women's_health_and_wellbeing_Issues_Paper.

Pleše, M., Dlačić, J. (2015). Creating a promotional message: exploring the role of nonverbal communication in advertising. Zbornik Veleučilišta u Rijeci, 3(1), 41-54.

Royce, T., \& Bowcher, W. (Eds.). (2006). New directions in the analysis of multimodal discourse. Mahwah, NJ: Lawrence Erlbaum Associates.

Šorm, E., \& Steen, G. J. (2013). Processing visual metaphor: A study in thinking out loud. Metaphor and the Social World, 3(1), 1-34. doi:10.1075/msw.3.1.01sor.

Sperber, D., \& Wilson, D. (1995). Relevance Theory. $2^{\text {nd }}$ ed. Oxford: Blackwell.

Todorova, R. (2002). America (real or imagined) in ads through the eyes of the beholder. America Imagined. Selected Conference Papers. Blagoevgrad, 166-170.

Todorova, R. (2013). Incongruity in advertising as prerequisite for conflict, change or adaptation of schemas. In E. Pancheva, C. Stamenov, M. Pipeva, \& G. Niagolov (Eds.). Peregrinations of the Text: Reading, Translation, Rewriting. Essays in Honour of Alexander Shurbanov. Sofia: Sofia University Press "St. Kliment Ohridski”. 453-460.

Todorova, R. (2015). Insights in Text Linguistics. From Theory to Practice. Shumen: Konstantin Preslavsky University Press.

Todorova, R. B. (2016). Expectation effects in Bulgarian advertising. In V. V. Vasilieva (Ed.). Language in the coordinates of mass media: papers for the I International Scientific Conference (September 6-9, 2016, Varna, Bulgaria). Media Linguistics. 5. St Petersburg: Higher School of Journalism and Mass Communications, 255-256. 


\section{Excerpted Sources:}

Snickers 1 (n. d.). Retrieved May 21, 2019 from https://sites.google.com/site/melanieharley 99/a.

Snickers 2. (n. d.). Retrieved May 21, 2019 from https://www.pinterest.com/pin/316237205 080534619 .

Snickers 3. (n. d.). Retrieved May 21, 2019 from https://www.manager.bg/reklama/eltndzhon-e-zvez data-v-nova-reklama-na-snickers-video.

Nestle Lion. (n. d.). Retrieved May 21, 2019 from https://www.vbox7.com/play:5f787525. 